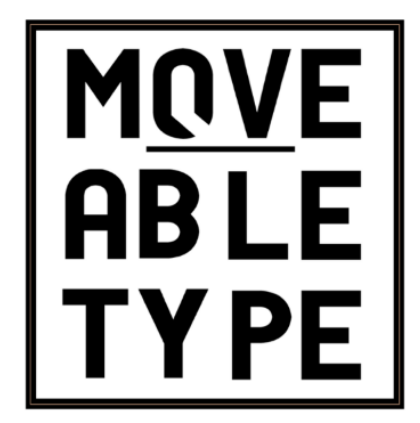

Article: John Clare and the Poetics of Mess

Author[s]: Mina Gorji

Source: MoveableType, Vol. 5, 'Mess' (2009)

DOI: $10.14324 / 111.1755-4527.042$

MoveableType is a Graduate, Peer-Reviewed Journal based in the Department of English at UCL.

(C) 2009 Mina Gorji. This is an Open Access article distributed under the terms of the Creative Commons Attribution License (CC-BY) 4.0https://creativecommons.org/licenses/by/4.0/, which permits unrestricted use, distribution, and reproduction in any medium, provided the original author and source are credited.

\title{
UCLPRESS
}




\section{John Clare and the Poetics of Mess}

John Clare's early poems were written on scraps - butter wrappers, sheets torn from of old copybooks and shop papers 'of all colors'. His mother found them stuffed into a hole in the kitchen wall and 'took them for kettle holders and fire lighters when ever she wanted paper, not knowing they were any thing farther then attempts at learning to write'. After this accident, Clare kept his poems close; he hid them in his pockets until 'the paper was chafd and torn through'. ${ }^{1}$ Even the surviving manuscripts are messy: scribbled with fading homemade ink in a scrawling handwriting, the spelling is irregular and the poems are left unpunctuated. But even after the drafts were tidied up and corrected by his first editors for publication, other forms of messiness remained. ${ }^{2}$

Clare's muse was scruffy: in 'The Flitting' he describes her relaxed attitude to dirt sitting down 'Upon the molehills little lap', she 'feels no fear to stain her gown'. Rejecting the 'gold \& pearls \& mystery' and 'haughty pomp' of 'high flown fangled things', she turns instead to 'crooked stiles', 'yellow furze' and 'teazle burrs'. Clare's writing is marked by attention to the stained, the mottled, the dishevelled, the broken and battered. He refused to gloss over what he called the 'dirty reality' of rural life. ${ }^{4}$ Weeds, molehills, brambles and waste ground all inspired his imagination. Perhaps our finest nature poet Clare is also a great poet of mess. His poetry engages with and displays messes of different kinds. Mess wasn't just a favourite subject, it was also a formal feature of his writing. Clare was not messy in the sense of being imprecise or rough, as in a sketch (a mode of descriptive writing and drawing popular in the early decades of the nineteenth century); his messes are particular and detailed; it is the ordering of the details, or rather, the apparent lack of order that contributes to the poem's messy feel. ${ }^{5}$ Their details don't always cohere into a larger whole. Often, they are loosely configured, a series of subtle perceptions and observations caught in what can seem to be an accidental sequence, catching at what Seamus Heaney has described as the 'one thing after another ness' of experience. ${ }^{6}$ The mess is true to life, but it was not true to certain notions of the poetical. They fail, for example, to manifest the intense orderliness of organic unity which Coleridge thought vital for poetry. Nor do they display the order and abstraction Reynolds recommended; he argued that 'the whole beauty and grandeur' of the art lies 'in being able to get above all singular forms, local customs, particularities and excrescences which serve only to "catch the sense" and "divide the attention". 7 Clare's poems catch and divide. They don't display the harmony and concord prescribed by Shaftesbury and Beattie, nor the smoothness and purity of diction Edward Bysshe pronounced as vital to the art of poetry. And yet Clare's poetic messes were not just failings, they could be artful and imaginatively suggestive. They are an example of what David Trotter has termed a 'poetics of mess', one which reveals itself in the practice of 'a degree of "formlessness": the invention of complicities with and figures for contingency'. 
Clare was writing at a time when mess was emerging as a concept. The word began as a simple noun; a mess was a kind of soup or a portion of food, but during the $19^{\text {th }}$ century it was enriched with figurative senses and came to represent kinds of disorder. A new sense of mess, as a state or condition, is recorded in OED '3. a. fig. A situation or state of affairs that is confused or presents numerous difficulties; a troubled or embarrassed state or condition; a predicament' (first usage 1812). ${ }^{9}$ Another new and related sense of mess was 'A dirty or untidy state of things or of a place; a collection of disordered things, producing such a state', OED 3, first usage 1826). These new varieties of mess might describe Clare's own bewildered condition: emotionally troubled, socially awkward, scruffy in appearance. Perhaps his disorderly writing betrayed the contours of a mind disturbed, the lineaments of mental confusion for which he would eventually be treated in various asylums. Or else it was a consequence, and a sign of his humble birth and lack of refinement. The son of a thresher, he lacked that outward polish and tidiness which would mark him as a gentleman and was embarrassed by his 'ragged coat and downy chin' in polite company. Clare knew that certain kinds of mess could operate as social signs both in relation to physical appearance and in writing; to appear scruffy, unkempt, dishevelled could be perceived to reveal low breeding and poverty. Conscious of his scruffiness, Clare felt out of place in the elegant literary world. But Clare's poetic messes weren't just symptoms of mental confusion, or signs his lowly social rank. Although he never used the word in his writing, he was alive to its senses and possibilities as a poetic device.

In the early nineteenth century irregularity came to be valued as a formal characteristic in a range of cultural forms including painting, landscape gardening and literature. The popularity of the ode, the rhapsody, and the rambling loco-descriptive poem testify to a new taste for disorder. ${ }^{10}$ Rather than simply a sign of incompetence, forms of messiness could suggest positive qualities such as sincerity, naturalness and spontaneity; they could also be a sign of genius. In the later eighteenth century, for example, Shakespeare's irregularity was celebrated as evidence of his natural genius. Where other poets, as Johnson went on to explain in his Preface to Shakespeare's works, 'display cabinets of precious rarities, minutely finished, wrought into shape, and polished into brightness', Shakespeare's writing was messy. He 'opens a mine which contains gold and diamonds in inexhaustible plenty, though clouded by incrustations, debased by impurities, and mingled with a mass of meaner minerals'. If his writing was a garden, it was not orderly and neat, but mingled 'myrtles and roses' with 'weeds and brambles'. 11

In Clare's writing, the weeds and brambles have taken over; they were favourite subjects of his poetry. In a sonnet of 1832 , he praises the ragwort:

Ragwort thou humble flower with tattered leaves

I love to see thee come \& litter gold

What time the summer binds her russet sheaves 
Decking rude spots in beautys manifold

That without thee were dreary to behold

Sun burnt $\&$ bare - the meadow bank the baulk

That leads a waggonway through mellow fields

Rich with the tints that harvests plenty yields

Browns of all hues - \& every where I walk

Thy waste of shining blossoms richly shield ${ }^{12}$

The ragwort was usually categorised as a weed by farmers and country people, disliked because it was poisonous to livestock. Clare was alive to its beauties, and to its messiness. A sense of its scruffy appearance is suggested by the word 'tattered', and by the 'rag' in ragwort. The $t$ sound in 'ragwort' connects it to a run of words associated with mess - 'tattered ... litter ...burnt', and 'waste' in the last line. Clare is celebrating the beauty of the uncultivated. In 'Decay - a ballad' (1832), he compares a disorderly natural landscape with the deliberate art of a cultivated garden:

The bank with brambles over spread

\& little molehills round about it

Was more to me then laurel shades

With paths \& gravel finely clouted

$\&$ streaking here $\&$ streaking there

Through shaven grass \& many a border

With rutty lanes had no compare

$\&$ heaths were in a richer order ${ }^{13}$

This is the art of accident rather than of deliberate design, a landscape shaped by nature and chance, rather than the human hand: the brambles and molehills emerge haphazardly, in no apparent order. And yet in this mess there is a 'richer order'. Molehills were also a favourite subject of Clare's; although they might appear to some as a nuisance, messing up the smooth contours of a field or lawn, for Clare they were a source of great beauty and imaginative interest. Moles brought history to the surface in the form of archaeological fragments and shards; molehills revealed traces of the past, by accident. ${ }^{14}$

Mess can challenge or disrupt the order of things; but it can also reveal an alternative order, one which is 'richer', that is to say a more suggestive and more imaginatively engaging and fruitful. Clare prefers the wilderness of the bank overgrown with brambles and molehills to the carefully landscaped gardens with their laurel shades and gravel paths. ${ }^{15}$ The word 'richer' comes as a surprise; it is from the same family of terms as 'laurel shades', 'paths and gravel finely clouted', part of a vocabulary of gardening and aristocratic beauty which Clare is setting against the beauty of disorder. Clare had himself worked as a landscape gardener as a young man; but he preferred the wild, uncultivated landscape. 
Clare's delight in disorder was, in part, a poetic response to the imposed ordering of the countryside around him. ${ }^{16}$ The enclosure of the farm and common-land in his Parish brought a tidy uniformity to the landscape. The fencing off of parkland and reorganisation of open spaces into larger, more regulated plots was designed to improve productivity. And yet it destroyed the variety of plant and wildlife, and limited the possibilities he had enjoyed to ramble through the landscape, freedoms and pleasures which he often celebrated in verse. In these lines, mess is associated with liberty:

There is a wild and beautiful neglect

About the fields that so delights and cheers

Where nature her own feelings to effect

Is left at her own silent work for years

The simplest thing thrown in our way delights;

From the wild careless feature that it wears

The very road that wanders out of sight

Crooked \& free is pleasant to behold

$\&$ such the very weeds left free to flower

Corn poppys red \& carlock gleaming gold

That makes the cornfields shine in summers hour

The crooked road is 'free' and 'wanders', the weeds are 'free to flower' here. The 'wild and beautiful neglect' allows a particular kind of experience in the landscape; the pleasures of random, chance encounters and discoveries. The unexpected is 'thrown in our way'; delight is accidental. Clare is celebrating the richness of contingency both as an experience in the world and in the texture of the verse. These lines express the unexpected metrically, by disrupting an established rhythmical order. The word 'thrown' disrupts the established metrical pattern - messes it up, if you like - and doing so, expresses in sound the surprise Clare experiences in the landscape, the experience of the unexpected. Here 'careless' and 'crooked' are terms of praise rather than censure. Clare celebrates the accidental, unexpected pleasures which can arise from neglect: left to run wild the landscape delights.

Many of Clare's poems describe the pleasures of wandering, ambling, soodling through fields and meadows, the pleasures of contingency. Sauntering through a newly ploughed field, Clare's eye is caught by a tumble of blossoming beans:

The south west wind how pleasant in the face It breathes while sauntering in a musing pace I roam these new ploughd fields \& by the side Of this old wood where happy birds abide $\&$ the rich blackbird through his golden bill Utters wild music when the rest are still

Now luscious comes the scent of blossomed beans 
That oer the path in rich disorder leans

Mid which the bees in busy songs \& toils

Load home luxuriantly their yellow spoils

The herd cows toss the mole hills in their play

$\&$ often stand the stranger's steps at bay

Mid clover blossoms red \& tawney white

Strongnscented with the summers warm delight ${ }^{17}$

Clare celebrates the 'rich disorder' of flowering bean plants spilling lusciously over the path. A sense of spilling is registered in the poem's enjambments; as in so much of Clare's best writing, messy style and subject are complicit. 'The Beans in Blossom' is a poem of fourteen lines long, but it seems to resists the shapes and rhetorical patterns we might expect from a sonnet. And yet if we look more closely, a subtler ordering pattern emerges. The poem is loosely divided into a sestet and an octet. The sense spills between the couplets of the first six lines, so that the third line is continuous syntactically with the first two - and the fifth line opens with an 'and'; the sense ends naturally at the word 'still'. There is a natural break in the syntax, emphasised by the pause implicit in the word 'still', and we begin a new clause with the insistent deictic 'now'. The next eight lines describe the scene without the presence of the 'I' of line 3; rather than sounds, the sensory perception described in these lines is the sense of smell. The poem then shifts from bees to cows in the meadows beyond, and ends by returning to the 'scent' of the seventh line, suggesting a circling close; there is a loose chiastic patterning so that the 'mid' which opens line 9 returns as the opening word of the thirteenth line, and the 'scent' of the seventh line returns at the start of line fourteen. Clare ruffles the conventions of the sonnet, but what emerges is another kind of patterning, an artful disorder.

Another kind of messiness is suggested syntactically. The poem doesn't build up to a single clause, no one image is in any meaningful way subordinate to any other; instead, detail accumulates on detail. But the details don't give the sense of a larger whole, as in eighteenth century landscape poetry, where each detail is carefully selected and the eye is guided to make out a total design. In Clare's lines, in contrast, it is not a design that is important so much as a rich simultaneity of perception he wants to achieve. He was committed to this authenticity of recording the totality and multiplicity of things in the world, as he experienced them. He refuses to leave anything out, to make the details subordinate to a larger whole. John Barrell has described this as an aesthetic of disorder, and explains, 'we feel ... that the syntax is trying to suggest that the images we apprehend as parts of a continuum were apprehended by Clare as a manifold of simultaneous impressions'. ${ }^{18}$ Trying, he implies, and failing. The syntax cannot accommodate this experience into a narrative order, and the result is disorder, confusion, a mess that is sign and symptom of failure.

To make a mess of something is 'to disorder, make dirty or untidy; to cause to be spoiled by inept handling; to muddle, mishandle' (as defined in $O E D$ ); and yet in 
poetry, making a mess can be an art. Metrically, a degree of messiness is necessary to a good poem. Poetry depends on the relation between order and disorder - a poem which was just regular iambics would be dead and dull. Rhythmically, of course, mess alone can't succeed - it must be balanced with, set against, order and pattern. Expressive variation from an established metrical norm is a source of pleasure in verse. In poetry, often, too much tidiness is a failure - poems can fall flat because they lack mess. Clare understood this instinctively; he admired Pope, but found his pastorals too tidy, their couplets, he explained, were too regular and smooth: 'the uninterrupted flow of the verses wearys the ear', he explained in a Journal entry for 4 October $1824 .{ }^{19}$ Of course this is an over simplification and undervaluing of Pope, who delighted in that 'grace beyond the reach of art ${ }^{20}$. But for all his metrical nimbleness, his ability to make the verse sound rough as the waves it describes, or the 'sense move slow' in a line which describes the huge effort of lifting a rock in order to convey that effort mimetically in the rhythm of the line, in his pastorals there is a kind of plodding regularity which Clare's ear picks up. ${ }^{21}$ Metrical disruption is necessary for interest to be sustained and it is also one of the ways in which a poem makes meanings.

In 'The Pettichaps Nest', Clare describes an unexpected discovery brought about by disruption:

Well in my many walks I rarely found A place less likely for a bird to form Its nest close by the rut gulled wagon road $\&$ on the almost bare foot-trodden ground With scarce a clump of grass to keep it warm \& not a thistle spreads its spears abroad Or prickly bush to shield it from harms way $\&$ yet so snugly made that none may spy It out save accident - \& you \& I Had surely passed it in our walk today Had chance not led us by it - nay e'en now Had not the old bird heard us trampling by $\&$ fluttered out - we had not seen it lie Brown as the road way side - small bits of hay Pluckt from the old propt-haystack's pleachy brow

$\&$ withered leaves make up its outward walls

That from the snub-oak dotterel yearly falls

$\&$ in the old hedge bottom rot away

Built like a oven with a little hole Hard to discover - that snug entrance wins Scarcely admitting e'en two fingers in $\&$ lined with feathers warm as silken stole $\&$ soft as seats of down for painless ease 
$\&$ full of eggs scarce bigger e'en then peas

Here's one most delicate with spots as small

As dust - \& of a faint $\&$ pinky red ${ }^{22}$

'Accident' is a key word here, emphasised by its placement just before a break in sense which is signalled by the dash, and by virtue of its difference; 'accident' is the only polysyllabic word in a line of monosyllables. The unexpectedness of the encounter is registered by the word 'chance', which is stressed in the slightly awkward formality of 'had chance not led us by it', at odds with the familiar idiomatic cadences of the rest of the poem. Mess is vital in expressing a sense of surprise in the following line; 'Had not the old bird heard us trampling by/ and fluttered out'. Here, three stresses are jammed in the phrase 'old bird heard', three stressed monosyllables which mess up the modulation of the iambic pentameter we have come to expect. This cluster of stresses is further emphasised by the rhyme of 'bird heard' and also consonantally: the three words 'old bird heard' all contain the $d$ sound, which picks up and repeats the $d$ in 'accident', and looks forward to the next line: 'And fluttered out'. There is a dynamic sense of release as we move from the compressed cluster of $d$ 's in 'old bird heard' into the lighter and more modulated 'and fluttered', which picks up a heavy set of stressed rhymes in 'old bird heard' more gracefully in 'fluttered', since the rhyme is unstressed.

Sound echoes sense in the description that follows. Like the nest, the poem's rhyme pattern is uneven and seemingly irregular, tightening into couplets and opening up into looser rhyming patterns. What seems to be messy has its own intricately irregular order. The delicate architecture of the nest is suggested in the patterns of rhyme and sound that run through the lines; the $p$ weaves through plucked propped pleachy, the $w$ threads through withered and walls. This poetic mess is very different from that in 'The Beans in Blossom'; rather than an 'aesthetic of disorder', an ambiguity of syntax and sense of multiplicity, the mess is precisely observed. The leaves are exactly described - they are withered and have fallen from the snub oak dotterel - the straw is plucked form the haystack's 'pleachy brow'.

In nineteenth century art and culture, mess often caused visceral disgust; one of the distinctive features of Clare's poetry is that mess can be appealing. Mess contributes to a distinctive sense of intimacy in his writing. ${ }^{23}$ Clare does not shrink from rot and detritus, he describes them closely and tenderly; he describes indelicate things with delicacy. In these lines from 'The Pettichap's Nest', the description of the nest is detailed and precise, moving carefully from its outer walls to the delicate eggs within, he creates a sense of intimacy, even a sexual intimacy. There is a delicacy of perception at work - but one that is not precious or fastidious. Here is a poet of acute and sensitive perception, who writes not only to the eye but also to the sense of touch; the textures and temperature of the nest are described, 'warm as silken stole'. And yet he is also alive to the dangers of touching something so delicate; a sense of fragility is suggested by the words used to describe the eggs and their patternings - 'delicate' and 
'dust' - and yet it is typical of Clare to use a word associated with mess to describe the pattern on the eggs. The word brings a fragility and also a kind of tender particularity to the description, one which is heightened by the precise but informal conversational cadence of 'pinky red'.

'The Pettichaps Nest' is one of a series of verses on bird nests which Clare wrote in the 1820 's and early 1830 's. In these poems, Clare found his own idiom, and a style for celebrating and expressing the art, and possibilities, of mess. Nightingales have long symbolized poetry, but Clare is perhaps the first to turn to its nest as a symbol of poetry. The nightingale's nest is hidden deep in brambles where 'crimping fern leaves ramp among the hazels under boughs', and where that 'Old-man's-beard all wildly trails/ Rude arbours o'er the road, and stops the way'. Revealed, once again, by accident, the nest is described in meticulous detail:

How curious is the nest no other bird

Uses such loose materials, or weaves

Their dwellings in such spots - dead oaken leaves

Are placed without \& velvet moss within

$\&$ little scraps of grass - \& scant $\&$ spare

Of what seems scarce materials down $\&$ hair

For from mans haunts she seemeth nought to win

Yet nature is the builder \& contrives

Homes for her childerns comfort even here ${ }^{24}$

The nest is made of litter and waste. Clare is characteristically exact: these aren't just leaves, but 'dead oaken leaves'. He describes the nest's uneven texture with sharp delicacy and in detail but it's not just the images of mess that are communicated, unevenness is also registered in the texture of his language, with its unlikely juxtapositions of register; the richness of "velvet moss" is offset by the sense of poverty suggested by the scraps of grass, scant and spare pieces of down and hair, and by the suggestion of scarcity ghosted in the word scarce.

Mess can obscure patterns and disrupt hierarchies; it can also reveal new orders, unexpectedly. In 'The Nightingale's Nest', an irregular form and informal cadences allow the subtle emergence of acoustic patterning. Because the poem's form is irregular, we don't have the same sense of expectation and anticipation that we might in regularly ordered verse. Instead, patterns emerge and retreat unexpectedly; the poem's form allows the reader to experience the pleasure of mess, the drama of discovery. ${ }^{25}$ A sense of the nest's intricate irregular structure in the architecture is suggested in and by the poem's sounds. Like the nest it describes, the poem's rhyme scheme is uneven and irregular; rhyming patterns emerge and retreat, couplets hold and then open up into longer unrhymed stretches. The rhyme suggests the intricate space and patterning of a nest. The word 'within' nestles between two pairs of rhymes, suggesting a chiastic pattern - weaves/leaves within spare/hair - so that we are 
surprised by having to wait three lines for its rhyme, "win", a word which both chimes with and is also contained in 'within'. The irregular form expresses both Clare's experience of discovery, and the nature of the nest itself - it is mimetic of and faithful to the experience of both subject and object. A confusion of subject and object is another characteristic of Clare's messy poetic. It is a slippage which characterises some of his finest writing, a kind of mess which allows the expression of new forms of subjectivity.

Describing birds' nests, Clare was often thinking about poetry. The birdnesting poems describe real encounters, but they also represent poetic inspiration. 'The Yellowhammer's Nest' explores this connection between poetry and nest:

Just by the wooden brig a bird flew up,

Frit by the cowboy as he scrambled down

To reach the misty dewberry - let us stoop

$\&$ seek its nest - the brook we need not dread

Tis scarcely deep enough a bee to drown

So it signs harmless oer its pebbly bed

- Aye here it is stuck close beside the bank

Beneath the bunch of grass that spindles rank

Its husk seeds tall \& high - tis rudely planned

Of bleached stubbles \& the withered fare

That last years harvest left upon the land,

Lined thinly with the horse's sable hair.

- Five eggs pen-scribbled over lilac shells

Resembling writing scrawls which fancy reads ${ }^{26}$

As in so many of Clare's poems this has a rambling, uneven quality. And yet despite the impression of artless spontaneity, it is deliberately crafted. Like the nest they describe, these lines are artfully messy - 'rudely planned'. Rude was a key word for Clare, one that he returned to and used over three hundred times in his own writing. ${ }^{27}$ It suggests the qualities associated with mess - imperfection, disorder, irregularity. Although for some the idea of rudeness or imperfection might seem antithetical to an idea of art, in Clare's poetry it is a virtue. Here, the mess is precisely observed and delicately described. The nest is also made of scraps - horse hairs, stubbles, left over pieces from the harvest. Inside the rudely planned nest, five eggs appear - these too are marked by mess, 'pen-scribbled' with 'writing scrawls'. Out of disorder patterns appear, messy writing - poetry. ${ }^{28}$

For Gaston Bachelard the nest was an example of the material imagination; for Clare, it embodies and symbolises the poetics of mess. ${ }^{29}$ His bird nest poems are the culmination, the most achieved examples of Clare's poetic; they describe and dramatise the chance delights and discoveries mess allows in their own artfully messy 
forms and textures. This is not an art of finished, perfect, completed forms, it is the poetry of the imperfect, the contingent, the poetry of accident.

\title{
MINA GORJI
}

\begin{abstract}
Mina Gorji is a Lecturer at the English Faculty of the University of Cambridge and a Fellow of Pembroke College. She is interested in the art of the uncultivated and her published works include a monograph, John Clare and the Place of Poetry, an edited collection, Rude Britannia, as well as essays on literary awkwardness, pastoral, working class poetry and weeds (forthcoming).
\end{abstract}

\footnotetext{
${ }^{1}$ John Clare, John Clare by Himself, ed. by Eric Robinson and David Powell (Manchester: Carcanet Press, 2002), pp.34 -165 (esp.98-99).

${ }^{2}$ How we interpret mess shapes how we evaluate the edited and corrected versions of Clare's manuscripts. Are the forms of messiness Clare's poems manifest authenticating or distracting? Is it accidental or deliberate? Is it artless or artful? Should it be tidied up or left? Is it part of his poetic meaning, or a distraction? Does leaving certain forms of mess behind contribute to a romanticised and potentially patronising image of Clare as an artless peasant poet? Or does it respect the integrity of his imagination? Are the messier manuscripts 'better' texts, or the cleaned up versions? The status and merits of different versions of Clare's poems has been the subject of considerable debate. See Zachary Leader, ed., Revision and Romantic Authorship (Oxford: Oxford University Press, 1996) and Hugh Haughton, Revision and Romantic Authorship: The Case of Clare, John Clare Society Journal, 17 (1998), 65-73; also available at <http://www.johnclare.info/haughton.html $>$ [accessed 2 March 2010]. 3 "The Flitting" (May-June 1832), John Clare, Poems of the Middle Period, IV, 1822-1837, eds. Eric Robinson, David Powell and P.M.S. Dawson (Oxford, 1998) pp. 479-489, 11. 178-9, 186, 36, 9, 11. ${ }^{4}$ Clare uses the phrase 'dirty reality' in a letter to William Hone of April 1825: 'I am sorry to bring a dirty reality so near your poetical description' (John Clare, Cottage Tales, eds. Eric Robinson, David Powell and P.M.S. Dawson (Ashington and Manchester, 1993), 'Appendix II', pp.138-143, p. 142.). The phrase is later used by Jonathan Bate to describe Clare's distinctive mode of pastoral in John Clare: A Biography (London: Picador, 2003), p.216.

${ }^{5}$ For a discussion of the Sketch as a mod and a genre in the $19^{\text {th }}$ century see Richard C. Sha, The Visual and Verbal Sketch in British Romanticism (Philadelphia: Pennsylvania University Press, 1998).

${ }^{6}$ Seamus Heaney, 'John Clare's Prog', The Redress of Poetry (London: Faber and Faber, 1995), pp.8081.

${ }^{7}$ Reynolds, Discourses, Discourse III, cited by David Trotter, Cooking with Mud: the Idea of Mess in Nineteenth-Century Art and Fiction (Oxford: Oxford University Press, 2000), p.40.

${ }^{8}$ Trotter, Cooking with Mud, p.31.

${ }^{9}$ This is a sense of mess as awkwardness I have described in more detail in 'Clare's Awkwardness', Essays in Criticism 54.3 (2004), 216-39.

${ }^{10}$ On formlessness as a feature of eighteenth-century rhapsody, see Sean Irlam, Elations: The Poetics of Enthusiasm in Eighteenth Century Britain (Stanford: Stanford University Press, 1999), p.3. For a discussion of the disorderliness characteristic of the eighteenth-century long poem, see Richard Terry, 'Transitions and Digressions in the Eighteenth-Century Long Poem', Studies in English Literature, 1500-1900, 32.3, Restoration and Eighteenth Century (1992), 495-510.

${ }^{11}$ Samuel Johnson, Mr. Johnson's Preface to Shakespeare's Plays (London, 1765), p.xxv.

12 "The Ragwort", Poems of the Middle Period, IV, 1822-1837,, pp. 324-325, 11. 1-10.

13 "Decay a Ballad", Poems of the Middle Period, IV, 1822-1837, pp.114-118, 11..11-18.

${ }^{14}$ For a more detailed discussion of the poetics of Clare's molehills, see Mina Gorji, 'Burying Bloomfield: Poetical Remains and "the unlettered' muse", in Robert Bloomfield: Lyric, Class, and the Romantic Canon, ed. by Simon White, John Goodridge and Bridget Keegan (Pennsylvania: Bucknell University Press, 2006), pp.232-52.

${ }^{15} \mathrm{He}$ sets out this opposition between order and the art of mess once again in a long and rambling poem 'Shadows of Taste' (1830): 'Some spruce \& delicate ideas feed/ With them disorder is an ugly weed/\& wood \& heath a wilderness of thorns/ Which gardeners shears nor fashions nor adorns/ No spots give pleasure so forlorn \& bare/ But gravel walks would work rich wonders there/ With such wild
} 
natures beautys run to waste/ \& arts strong impulse marrs the truth of taste', Poems of the Middle Period, IV, 1822-1837, pp. 303-310, 11. 153-160.

${ }^{16}$ See John Barrell for a fuller account of this response to enclosure, in The Idea of Landscape and the Sense of Place, 1730-1840. An Approach to the Poetry of John Clare (London: Cambridge University Press, 1972).

17 “The Beans in Blossom" (1819-1832), Poems of the Middle Period, IV, 1822-1837, pp.191-192.

${ }^{18}$ Barrell, The Idea of Landscape and the Sense of Place, p. 157.

${ }^{19}$ Clare, 'The Journal', in John Clare By Himself, pp.171-244 (p.189).

${ }^{20}$ Alexander Pope, “An Essay on Criticism”, (1711), Poetical Works of Alexander Pope, ed. Herbert Davies (Oxford, 1978), p. 68, 1. 153.

21 Alexander Pope, "An Essay on Criticism", 11.367- 371 "And the smooth Stream in smoother Numbers flows;/But when loud Surges lash the sounding Shore,/ The hoarse, rough Verse shou'd like the Torrent roar./ When Ajax strives, some Rocks' vast Weight to throw,/The Line too labours, and the Words move slow...'. Clare's sense of Pope's tedious metrical regularity might itself have been shaped by cultural attitudes to Pope in the Romantic period: the idea of Pope as a boringly regular Neoclassical writer who obeyed order rather than exhibited wild genius, whose Pegasus was a rocking horse (Keats, 'Sleep and Poetry' (1817), The Poems of John Keats, ed. Miriam Allott (London and New York, 1970), pp.69-85, 11. 185-7; Keats is reworking Hazlitt's account of Pope as one who would take Milton's Pegasus and transform it into a rocking horse in his 1815 Round Table essay 'On Milton's Versification'. For a discussion of Romantic attitudes to Pope see Robert John Griffin, Wordsworth's Pope: a Study in Literary Historiography (Cambridge: Cambridge University Press, 1995).

22 "The Pettichaps Nest" (1825-6), Poems of the Middle Period, IV, 1822-1837, 11. 517-519, 11. 1-26

${ }^{23}$ For a discussion of mess and disgust, see Trotter, Cooking with Mud.

24 “The Nightingale's Nest” (1832), John Clare, Poems of the Middle Period, III, 1822-1837, pp.456461, 11. 76-84

${ }^{25}$ This pleasure of discovery is related to the experience of mess described by Adam Phillips in 'Clutter: A Case History'. Discussing Francis Bacon's messy techniques, he argues that, 'In clutter you may not be able to find what you are looking for, but you may find something else instead, while you are looking for it'. Adam Phillips, 'Clutter: A Case History', in Promises, Promises: Essays on Poetry and Psychoanalysis (London: Faber and Faber, 2000), pp.59-71 (p.64).

26 “The Yellow Hammer's Nest” (1826-6), Poems of the Middle Period, IV, 1822-1837, pp. 515-517, 11.1-14.

${ }^{27}$ See Mina Gorji, John Clare and the Place of Poetry (Liverpool: Liverpool University Press, 2008), pp.15-18, 21, 24-26, 28-30, 33-34, 54, 60.

${ }^{28}$ The image of the pen-scribbled eggs recurs in "Shadows of Taste" (1830); the "writing larks" have eggs which are "scribbled as with ink \& pen", Poems of the Middle Period, IV, 1822-1837, pp. 303310, 1. 12.

${ }^{29}$ Gaston Bachelard, The Poetics of Space, trans. by John R. Stilgoe, (Boston: Beacon Press, 1994), pp.90-104. 